\title{
Perselingkuhan Politik Ammatoa:Kajian Antropologi Politik Di Kajang, Bulukumba
}

\author{
Moh Ilham A Hamudy \\ Departemen Dalam Negeri \\ ilham@yahoo.com
}

Kajang community is one of traditional communities in South Sulawesi. The community, led by Ammatoa, has philosophy of life in the form of oral narrative called as pasang ri Kajang (holy messages from Kajang), inherited from generation to generation. In daily life the community members strongly hold pasang ri Kajang, and consider it as the teaching of their ancestors. However, the tradition and values of pasang ri Kajang have changed. This is seen from the fact that many Kajang people frequently show deviant behavior, including lying, nepotism, stabbing from the back, short cutting, and 'deceitful'. Political intrigue, patronclient, fraudulent, and political deceitful conducts between Ammatoa and 'Pak Dewan' have strengthened the above fact. As a consequence, pasang ri Kajang has not been considered as rules existing in the plural values of Kajang community. The elements of pasang ri Kajang have sunk in the complexity of modernization, and in the politization of Kajang elites. This further leads to the presumption that the tradition of Kajang people cannot be used anymore to answer challenges from new values that are relevant and rationale.

Keywords: Kajang community, Ammatoa, pasang ri Kajang, deviant behavior, deceitful.

\section{Pendahuluan}

Dabu, 30 Mei 2004 silam, sebuah pertemuan besar digelar di tanah adat komunitas Kajang, Kabupaten Bulukumba Sulawesi Selatan. Pertemuan itu dihadiri oleh Muspida Bulukumba dan seluruh pemangku adat komunitas Kajang.

Komunitas Kajang adalah salah satu komunitas adat di Sulawesi Selatan. Komunitas ini memiliki panduan hidup dalam bentuk tuturan lisan yang disebut pasang $r i$ Kajang (pesan-pesan suci dari Kajang) yang sudah dilestarikan dari generasi ke generasi. Dalam kehidupan sehari-hari, masyarakat Kajang memegang teguh pasang ri Kajang yang juga adalah ajaran leluhur mereka. Pertama, ta'ngu'rangi mange ri Tu Rie' A'ra'na yang berarti senantiasa ingat pada Tuhan Yang Berkehendak. Karena ingat, berarti tidak akan melanggar aturannya.
Kedua, a'lemo sibatang, a'bulo sipappa', tallang sipolua, manyu siparampe, sipakatau tang sipakasiri yang artinya, memupuk persatuan dan kesatuan dengan penuh kekeluargaan dan saling memuliakan. Ketiga, lambusu kigattang sa'bara ki peso'na, berarti bertindak tegas tetapi juga sabar dan tawakkal. Keempat, sallu riajuka, ammulu riaddakang ammaca' ere anreppe' batu, alla'buirurung, alla'batu cideng. Artinya, harus taat pada aturan yang telah dibuat secara bersama-sama kendati harus menahan gelombang dan memecahkan batu gunung. Kelima, nan nigaukang sikontu passuroang to ma' buttayya yang artinya, melaksanakan segala aturan secara murni dan konsekuen. Kelima ajaran inilah yang menjadi pedoman masyarakat dan para pemimpin dalam kehidupan sehari-hari. Dari kelima pesan ini, lahir prinsip hidup sederhana (kamase-mase) dan saling 
menyayangi di antara mereka. Menurut Asdar, salah seorang suku Kajang yang sudah lama berdiam di Makassar, selain kelima pesan ini, ada hal lain yang juga mengikat masyarakat yakni setiap warga Kajang harus kawin dengan sesama orang dalam kawasan adat. Yang kebetulan bertemu jodoh dengan orang luar kawasan adat, harus siap-siap meninggalkan kawasan adat. Pengecualian bila pasangannya mau mengikuti segala aturan dan adat-istiadat yang berlaku di dalam kawasan adat.

Sebagai pemimpin adat, ditunjuk seorang pimpinan yang disebut Ammatoa (pemimpin tertua), lalu di bawahnya ada pemangku adat lain sesuai dengan bidangnya masing-masing. Dalam pertemuan antara berbagai elemen itu, soal utama yang dibahas adalah munculnya dua Ammatoa. Saat itu ada dua orang yang mengaku menjadi Ammatoa, yaitu Puto Palasa dan Puto Bekkong.

Pertemuan dipandu oleh pemangku adat yang bergelar Galla, yaitu Galla Lombo'. Sebelumnya, ia menjelaskan mengenai aturan dalam pasang ri Kajang dalam proses pemilihan Ammatoa. Di sana dikatakan bahwa yang berhak mendapat gelar Ammatoa adalah yang sanggup melewati proses pengangkatan yang terdiri dari empat tahapan.

Dalam kesaksian salah satu pemangku adat, empat tahapan itu sudah dilalui oleh keduanya. Dalam proses itu Puto Palasa yang berhasil melalui empat tahapan.

Dalam pertemuan itu, tidak dijelaskan secara rinci mengenai tahapan yang mesti dilalui dalam pemilihan Ammatoa. Bahkan, hampir setiap informan yang saya jumpai, mengatakan tidak tahu persis rangkaian tahapan pemilihan Ammatoa. Kalaupun mereka tahu, itu hanya informasi yang mereka dengar dari orang lain. Sebab, tidak semua orang diperkenankan hadir dalam pelantikan itu. Hanya orang-orang tertentu yang dianggap memiliki "ilmu” yang cukup saja yang diperkenankan hadir dalam pelantikan. Di samping itu, dalam tradisi Kajang, aturan-aturan ritual yang sakral itu tidak dituliskan dalam sebuah buku pedoman. Tetapi, hanya dituturkan secara lisan dari generasi ke generasi. Sehingga, bisa dibayangkan, informasi yang beredar simpang siur. Tentang hal ini akan saya uraikan lebih lanjut pada bagian lain tulisan ini.

Sebagai bahan perbandingan, simak juga uraian Katu (2005:55-57) dalam tulisannya "Tasawuf Kajang".

Dalam ilmu politik dikenal dengan istilah politik enumeratif (enumerative politics) yang mengkomodifikasi simbol-simbol komunitas seperti agama dan etnis, lebih menggalang dukungan suara daripada sebuah partisipasi, apalagi pencerapan aspirasi.

Para calon gubernur/wakil gubernur yang bertarung pada Pilkada Sulsel tanggal 5 November 2007 silam berkampanye hingga ke kawasan adat Tana Toa. Seperti kesaksian yang dituturkan Pak Sekdes Tana Toa kepada saya, tim sukses salah satu kandidat, yang juga incumbent, Amin SyamMansyur Ramli (ASMARA) mendekati Ammatoa. Bahkan, meminta perlindungan spiritual. Menurut Pak Sekdes, hari itu sudah menjelang pukul 15.00 wita, Ammatoa, dengan didampingi beberapa anggota adat, berjalan kaki menuju balai pertemuan yang terletak di ujung perbatasan Dusun Benteng dan Dusun So'bu. Ammatoa datang untuk menghadiri pertemuan, tanpa baju, tanpa sandal, hanya celana kolor hitam, passappu di kepala, dan tope le'leng (sarung hitam) disilangkan di tubuh. Ammatoa tampak terburu-buru. Tidak lama kemudian, ruang tamu yang tadinya sepi 
UNISIA, Vol. XXXI No. 70 Desember 2008

sudah diisi sekira 20 -an orang. Ammatoa duduk di "singgasana"-nya beralaskan tikar bersandarkan bantal, di salah satu sudut balai. Lalu, salah seorang anggota tim sukses mengutarakan maksudnya kepada Ammatoa dan beberapa perangkat adat yang hadir, salah satunya Galla Kajang, untuk mendukung pasangan ASMARA. Anggota tim sukses itu, pun dengan nada mengiba mengatakan bahwa lawan-lawan ASMARA sudah mengunjungi 100 dukun untuk membunuh ASMARA. Untuk itu, dia meminta Ammatoa untuk membentengi ASMARA dengan ilmunya. Tidak lama kemudian, orang Kajang yang mengantar tim sukses ini mempersilakan orang kepercayaan ASMARA untuk mendekat ke Ammatoa guna menerima "mantra-mantra". Sebelumnya, Ammatoa "membaca-bacai" dulu air mineral di dalam botol besar yang dituangkan ke gelas besar. Setelah diberi mantra, air kembali dituangkan kembali ke dalam wadahnya. Ammatoa menginstruksikan air tersebut dicampur dengan air minum Amin Syam agar tidak kena ilmu hitam. Dengan takzim anggota tim sukses itu mengiyakan.

Sementara Puto Bekkong, tidak sampai mengikuti seluruh tahapan. Oleh karena itu, secara hukum adat Kajang, yang berhak menjabat Ammatoa adalah Puto Palasa yang usianya lebih muda dari Puto Bekkong. Dari hasil ini diputuskan bahwa Puto Palasa yang berhak menjadi Ammatoa.

Namun, sebelumnya, pada hari Rabu juga, 21 April 2004 sekira pukul 9.30 wita, telah berlangsung pertemuan serupa, dihadiri para pemangku adat butta Kajang. Dengan dipimpin oleh Karaeng Tallu (Labbiria, Sulewatang, dan Anak Karaeng Moncongbuloa) dan disaksikan warga komunitas adat Kajang dan unsur pemerintah setempat, pertemuan tersebut berusaha mencari solusi dualisme Ammatoa.
Pertemuan itu berusaha membahas duduk perkara terjadinya dualisme dan mendamaikan dua kubu yang bersengketa, antara pihak Puto Bekkong dan Puto Palasa (keduanya merasa sebagai Ammatoa). Akhirnya, setelah melewati urun rembug yang menyita waktu hampir enam jam, disepakati yang menjadi Ammatoa adalah Puto Bekkong. Keputusan tersebut diambil berdasarkan pengakuan Anrongta ri Pangi, orang yang berhak melantik Ammatoa. Dalam pengakuannya, beliau mengatakan:

Oh anakku ia ngase irate nasaba maengmi kulantik Ammatoa siurang atoran riolo mariolo, iamintu i Puto Bekkong. Kuerai nupalekkoki nanutimbahoi, nasaba malla inakke allese riatoran riolo mariolo. Inakke tanggung jawab ri lino, sambenna ri allo ri boko saba tojeng nasiurang kalambusang, kupaingakko anak:

Lambusukko nu karaeng. Pissonaku nu guru.

Gattangko nu ada. Sabbarakko nusanro.

Salama kointu ri lino sambenna ri allo ri boko

Akko jamaii punna tania jamannu

Artinya: Hai anakku, berdasarkan aturan yang berlaku turun temurun, dengan ini sudah saya lantik yaitu Puto Bekkong sebagai Ammatoa. Saya tidak menyeleweng dari aturan nenek moyang kita. Saya bertanggung jawab di dunia dan akhirat atas apa yang sudah saya lakukan. Saya ingatkan kamu anakku:

Lurus dalam memerintah. Pasrah seperti ulama.

Tegas pada aturan adat. Sabar seperti orang yang berilmu tinggi.

Niscaya kamu akan selamat di dunia dan akhirat kelak. 
Jangan mengerjakan hal yang bukan pekerjaanmu.

Ketika mengetahui peristiwa itu dari informan, saya sedang mengkaji fenomena politik di Kajang, karena banyak orang yang menganggap, kontestasi politik di Kajang relatif lebih sengit dibandingkan dengan kecamatan lain yang ada di Bulukumba. Tidak jarang di antara sanak saudara mereka berselisih paham, hanya karena pandangan dan afiliasi politik yang berbeda. Sebagian besar warga Kajang menjadi pengurus partai politik. Sehingga, tidak heran dapat kita jumpai pelbagai bendera partai politik yang berbeda di setiap rumah warga. Istilah warga setempat, ero ngaseng appaenteng bandera. Masing-masing warga ingin mendirikan bendera partai politik sendiri.

Saya telah mendengar banyak kisah tentang seorang calon legislatif (caleg) yang menghalalkan segala cara untuk meraih kekuasaan, meski harus mengabaikan pasang. Kisah tentang bagaimana para politisi Kajang selalu menjual isu marginalisasi orang Kajang dalam segala bidang. Namun, setelah terpilih, para politisi itu mengabaikan isu marginalisasi yang pernah ia hembuskan. Alih-alih mengentaskan warga Kajang dari marginalisasi, malahan para politisi itu mengeruk keuntungan dari marginalisasi orang Kajang. Orang Kajang, tetap terpinggirkan.

Kisah-kisah tentang politisi yang terjebak pesona magis, bersekutu dengan setan, untuk mendapatkan kekuasaan, sebuah tindakan irrasional dalam politik modern. Saya menyimak secara hati-hati terhadap kisah ini, tetapi sebagian juga memahaminya sebagai hiperbola orang Kajang yang tipikal.

Kebanyakan orang Kajang yang saya jumpai menganggap, adanya dualisme kepemimpinan Ammatoa tidak terlepas dari keterlibatan Ammatoa dalam kontestasi kekuasaan di antara partai politik dan caleg. Mereka saling berebut dukungan Ammatoa yang memiliki pengaruh di seantero Kajang.

Sebagai contoh, salah seorang caleg DPRD Sulsel, dari Partai Persatuan Pembangunan (PPP), kembali melakukan kunjungan ke Bulukumba. Dari 10 kecamatan di daerah ini, ia mengaku sudah menyisir seluruhnya. Kemarin, ia kembali menyisir wilayah pedalaman Kecamatan Kajang. Di wilayah itu, ia melakukan sejumlah pertemuan dengan masyarakat setempat seperti di Kelurahan Kassi, hingga wilayah paling terpencil di kawasan adat Kajang. Bahkan, ia pun melakukan silaturahmi ke pemangku adat, Ammatoa, Puto Palasa. Caleg urut 1 dapil III meliputi, Bantaeng, Bulukumba, Selayar, dan Sinjai itu mengaku, hanya melakukan silaturahmi dengan pemangku adat. "Saya diundang silaturahmi, sekaligus sosialisasi," dalihnya. Padahal, maksud sesungguhnya adalah minta dukungan dari Ammatoa.

Sesiapa yang dekat dengan Ammatoa, otomatis merasa memiliki lumbung suara. Sementara Ammatoa pun mengeruk keuntungan dari partai politik dan caleg berupa perlindungan kekuasaan di hadapan pemerintah daerah dan materi, tentu saja. Dulu, pada era sebelum 1980an, Ammatoa tidak pernah mau menerima pemberian dari sesiapa pun. Namun, setelah era itu, Ammatoa dengan senang hati menerima semua pemberian tamu yang menyambanginya. Tetamu yang sowan biasanya memberi makanan atau pun uang. Jadi, secara tidak langsung, orang yang terpilih sebagai Ammatoa, otomatis sangat menikmati "keuntungan" itu. Orang Kajang pada umumnya miskin dan tidak terdidik. Tetapi, dalam hal politik, hampir semuanya melek politik.

Mencermati inti ajaran kamase-masea suatu konsepsi hidup dengan muatan: 
lambusu' (lurus), gattang (tegas), sa'bara (sabar), apisona (pasrah). Konsepsi hidup ini mengutamakan kehidupan yang "miskin" di dunia, dengan harapan akan menikmati "kekayaan" yang kekal di akhirat nanti (kalumannyang kalupepeang). Prinsip ini diselimuti oleh ikatan-ikatan emosi yang menjadi bagian yang tidak terpisahkan dari sistem kepercayaan. Karena, mengandung nilai-nilai keramat yang disertai "imbalan" dan "sanksi" yang juga keramat. Untuk mengekang hawa nafsu, jujur, rendah hati, tidak merugikan orang lain, dan menjaga keseimbangan alam, tidak tergoda kekuasaan duniawi, patut diduga bahwa pengingkaran atas nilai-nilai itulah yang jadi biang terjadinya dualisme Ammatoa.

Tulisan ini membincangkan kontestasi kekuasaan di Kajang dan perselingkuhan politik Ammatoa. Argumentasi yang diajukan dalam tulisan ini menjelaskan bahwa realitas munculnya dualisme Ammatoa, mengindikasikan kontestasi politik di Kajang, tidak hanya domain politik modern di antara partai politik dan caleg, tetapi juga politik tradisional dalam komunitas adat. Orang Kajang yang dianggap memiliki stereotipe yang bersahaja, berpegang pada prinsip tallasa kamase-masea. Secara harfiah, tallasa kamase-mase berarti hidup memelas, hidup apa adanya. Memelas, dalam arti bahwa tujuan hidup warga masyarakat Kajang menurut pasang adalah semata-mata mengabdi kepada Tu Rie' A'ra'na. Prinsip tallasa kamase-mase, berarti tidak mempunyai keinginan yang berlebih dalam kehidupan sehari-hari, baik untuk makan, maupun dalam kebutuhan pakaiannya. Dengan cara yang demikian, maka keinginan mendapatkan hasil berlebihan dari dalam hutan dapat dihindari, setidak-tidaknya dapat ditekan seminimal mungkin, sehingga hutan tidak terganggu kelestariannya (Salle, 2000).
Hidup sederhana bagi masyarakat Kajang adalah semacam ideologi yang berfungsi sebagai pemandu dan rujukan nilai dalam menjalankan kehidupan sehari-hari. Secara lebih jelas tallasa kamase-mase ini tercermin dalam pasang sebagai berikut: Pertama, ammentengko nu kamase-mase, accidongko nu kamase-mase, a'dakkako nu kamasemase, a'meako nu kamase-mase. Artinya, berdiri engkau sederhana, duduk engkau sederhana, melangkah engkau sederhana, dan berbicara engkau sederhana. Kedua, anre kalumannyang kalupepeang, rie kamasemasea, angnganre na rie, care-care na rie, pammalli juku na rie, koko na rie, bola situjutuju. Artinya, kekayaan itu tidak kekal, yang ada hanya kesederhanaan, makan secukupnya, pakaian secukupnya, membeli ikan secukupnya, kebun secukupnya, rumah seadanya. Ketiga, jagai lino lollong bonena, kammayatompa langika, rupa taua siagang boronga. Artinya, peliharalah dunia beserta isinya, demikian pula langit, manusia dan hutan. Hidup sederhana, jauh dari persoalan materi yang duniawi, ternyata tidak luput dari godaan kekuasaan yang kemaruk. Alih-alih Ammatoa yang semestinya berperan sebagai pemimpin adat dan penjaga moral prinsip kamase-masea dalam pasang ri Kajang, tetapi malah terlibat dalam perselingkuhan politik.

\section{Kajian Pustaka}

Pak Desa Tambangan memandu saya menyusuri jalan beraspal yang keropos dan berdebu menuju kediamannya di Desa Tambangan, Kecamatan Kajang. Mobil Honda CRV yang kami tumpangi bekerja setengah mati menaklukan jalan yang rusak berat. Sepanjang jalan Pak Desa bercerita pelbagai hal tentang komunitas adat Kajang, mulai dari budaya setempat, beberapa peristiwa terkini yang terjadi di Kajang, 
masalah-masalah politik, sampai pada halhal mistik yang membuat saya bergidik. Saya diingatkan untuk berlaku semadyanya pada orang Kajang. Sikap atau perbincangan yang membuat orang Kajang terhina akan berimpak fatal pada keselamatan saya. Sontak saya teringat dengan cerita kawan saya yang mengatakan bahwa kalau orang Kajang sudah marah dan dendam kesumat, bisa-bisa kepala kita jadi lembek. Stereotipe orang Kajang yang dekat hal-hal mistik ini selalu saja menempel dalam kepala "orang luar" yang belum atau tidak pernah mengenal orang Kajang secara utuh. Saya mencermati dengan saksama dan mengikuti semua penjelasan dan saran beliau.

Selama sekira satu jam kemudian, kami sampai di kediaman beliau di Desa Tambangan. Hari itu sudah menjelang pukul 16.00 wita. Sembari menyeruput teh panas dan menikmati jajanan pasar, Pak Desa kembali bercerita dan menanyakan fokus penelitian saya. Awalnya, Pak Desa menyarankan saya untuk tinggal di rumahnya saja. Menurutnya, kajian politik yang akan saya teliti sangat tepat jika dilakukan di Desa Tambangan. Sebab, menurutnya, kontestasi politik di Tambangan relatif lebih sengit dibandingkan desa lain di Kecamatan Kajang. Selain itu pula, hampir semua caleg yang ada di daerah pemilihan (Dapil I ini mencakup Kecamatan Kajang, Herlang dan Bontotiro) berdomisili di Tambangan. Sehingga, akan memudahkan saya untuk mewawancarai para caleg tersebut. Kendati begitu, saran Pak Desa saya tampik dengan halus. Meski Tambangan sangat menarik untuk dijadikan lokus penelitian, saya lebih memilih Desa Tana Toa sebagai lokus utama. Alasannya, komunitas adat Kajang terpusat di Desa Tana Toa. Sementara di Desa Tambangan, struktur masyarakat sudah mengarah kepada desa urban, hal yang kurang tepat dalam penelitian saya. Setelah meyakinkan Pak Desa, akhirnya saya diantar menuju Desa Tana Toa yang jaraknya lumayan jauh, sekira 10 km dari Desa Tambangan. Saya yakin, tinggal di Desa Tana Toa akan banyak membantu saya untuk memahami masyarakat Kajang dan kehidupan desa seharihari.

Tulisan ini didasarkan pada penelitian lapangan yang saya lakukan di dan sekitar Tana Toa selama hampir 2,5 bulan. Komunitas adat Kajang berdomisili di Kecamatan Kajang, Kabupaten Bulukumba. Secara umum, dapat dicandrakan, wilayah Bulukumba (Butta Panrita Lopi) terhampar seluas $11.547,6 \mathrm{~km}^{2}$. Berada di sebelah timur gugus pegunungan Lompobattang-Bawakaraeng. Secara astronomis, Bulukumba terletak pada $5^{\circ} 16^{\prime} 53^{\prime \prime}$ dan $50^{\circ} 39^{\prime} 39^{\prime \prime}$ LS serta $119^{\circ} 54^{\prime} 27^{\prime \prime}$ dan $120^{\circ} 27^{\prime} 33^{\prime \prime}$ BT. Bulukumba merupakan wilayah paling selatan Provinsi Sulawesi Selatan. Bulukumba juga bersempadan dengan Teluk Bone di sebelah timur, berhadapan dengan laut Flores di sebelah selatan, di bagian utara bersempadan dengan Kabupaten Sinjai dan Kabupaten Bantaeng di sebelah barat. Di sebelah tenggara terdapat Selat Selayar yang memisahkannya dengan Pulau Selayar.

Adapun Kecamatan Kajang adalah daerah berbukit. Sebagian tanahnya berbatu, sebagian lagi tanah liat, dan di bagian pesisir dan pinggir sungai berawarawa. Dataran tertinggi (331 m) terdapat di Desa Tana Toa, lokus utama penelitian saya. Di kawasan bukit dan hutan, mengalir Sungai Raoa, mengairi persawahan yang dilewati dan bermuara di Pantai Kassi, lalu mengalir ke Teluk Bone. Sungai ini memisahkan Kelurahan Tana Jaya dengan Desa Possi Tana. Di sepanjang sisi Sungai Raoa, dari muara hingga puluhan kilometer ke 
UNISIA, Vol. XXXI No. 70 Desember 2008

darat, tumbuh hutan manggrove yang lebat. Adanya muara sungai dan perairan teluk Bone, menjadikan Kassi, ibukota Kecamatan Kajang ini, ideal sebagai pusat perkampungan nelayan.

Luas Kecamatan Kajang sekira 154,30 $\mathrm{km}^{2}$ terdiri dari 17 desa dan dua kelurahan. Sebagian besar wilayah Kecamatan Kajang terdiri dari perkampungan, sawah, ladang, kebun, rawa, hutan, dan tanah kosong. Di pesisir timur membentang pantai sepanjang $15 \mathrm{~km}$. Di sepanjang pantai berkembang komunitas nelayan: kampung Babalaikang paling selatan, selanjutnya Laikang, Jalaya, Ta'rongkolang, Kassi, Lombo' dan Lolisang. Di persempadanan sebelah utara dengan Kabupaten Sinjai, mengalir Sungai Lolisang yang bermuara di Teluk Bone. Di selatan Kajang bersempadan dengan Kecamatan Ujung Bulu dan Herlang. Di sebelah barat bersempadan dengan Kecamatan Bulukumpa. Di wilayah persempadanan antara Kajang dengan Bulukumpa terdapat perkebunan karet. Di perkebunan karet tersebut, pada 21 Juli 2003 pernah terjadi bentrokan fisik antara warga komunitas Kajang dengan PT. London Sumatera (Lonsum). Sebenarnya, kasus ini bermula pada 1982, saat warga komunitas Kajang mengklaim lahan perkebunan karet milik PT. Lonsum yang terletak di Dusun Ganta, Desa Bonto Biraeng, seluas $350 \mathrm{Ha}$. Warga berdalih, lahan itu tanah garapan yang telah dikuasai dan digarap warga secara turuntemurun selama sekitar 28 tahun. Oleh karena itu, mereka meminta ganti rugi atas pemanfaatan Iahan tersebut. Untuk menyelesaikan persoalan tersebut, warga mengajukan gugatan perdata ke Pengadilan Negeri Bulukumba. Hasilnya, majelis hakim memenangkan gugatan warga. Tetapi, bukan 350 hektar lahan, melainkan 200 hektar. Pihak PT. Lonsum mengajukan banding ke Pengadilan Tinggi yang dilajutkan dengan kasasi ke Mahkamah Agung. Pada proses pemeriksaan kasasi terjadi perdamaian. PT. Lonsum setuju menyerahkan 143 hektar tanah sengketa pada penggugat. Namun penggugat tidak merasa puas dan berlanjut dengan bentrokan fisik yang menelan korban jiwa.

Sedangkan Desa Tana Toa, adalah desa yang letaknya di ujung barat Kecamatan Kajang. Desa Tana Toa adalah desa yang ideal bagi saya untuk melakukan penelitian tentang bagaimana budaya Kajang dan politik ditengahi oleh derasnya arus modernitas. Dalam banyak hal, Tana Toa lebih mewakili pusat komunitas budaya Kajang, yang berbeda dengan desa-desa lain di Kecamatan Kajang yang lebih urban. Desa Tana Toa secara tipikal menjadi fokus penelitian antropologis. Selain itu pula, di desa ini, ada seorang komunitas Kajang yang menjadi wakil rakyat di DPRD Kabupaten Bulukumba. Saya menginsyafi bahwa Pak Dewan, karena sudah menjadi anggota DPRD Bulukumba, warga Tana Toa kerap memanggilnya dengan sebutan Pak Dewan yang juga mantan Galla Lombo', wakil rakyat tersebut, merupakan representasi politik komunitas Kajang yang paling konkret dalam percaturan politik di Bulukumba.

Letak astronomi Tana Toa berada pada titik koordinat $02^{\circ} 59^{\prime} 25^{\prime \prime}$ diukur dari Dusun Benteng yang dianggap sebagai kawasan inti permukiman masyarakat Kajang. Menurut tetua adat Kajang, wilayah komunitas adat Kajang cukup luas. Mereka menamakannya dengan sebutan Rambang Luara (yang terdiri dari Save, Solo, Salaparang, Tambelu, Tambora, Ambon, sampai ke Ternate). Wilayah itu menyempit, meliputi hanya Tanuntung (Herlang), Tammatto (Ujung Lohe), Buatanang (Bulukumpa), Sangkala Lombo' (Kajang). Kemudian, menyempit lagi menjadi Dalonjo 
(Balagana), Tana Toa, Dakodo (Teteaka Tambangan), Damanga Salang (Balangbina). Lalu menyempit lagi meliputi Sobbu, Tobe (di Desa Malleleng), Tombolo, dan Balangbina. Sekarang, tanah adat yang dihuni oleh orang Kajang yang masih teguh memegang pasang, hanya terdiri dari Dusun Pangi, Benteng, Bongkina, Tombolo, Balangbina, dan Dusun Lurayya. Kesemuanya itu tercakup dalam wilayah Tana Toa. Malahan, sebenarnya, yang benar-benar murni adat Kajang, hanya terdapat di dua dusun saja di Tana Toa, yaitu Dusun Benteng dan Bongkina. Sebab, di kedua dusun itulah yang benar-benar steril dari produk modernitas. Selebihnya, sudah terkontaminasi modernitas. Selain di dua dusun itu, orang luar boleh masuk tanpa menggunakan pakaian gelap (hitam ataupun biru dongker). Bahkan, kendaraan seperti sepeda motor, sudah bisa masuk dengan bebas.

$\mathrm{Hal}$ ini mempertimbangkan bahwa Dusun Benteng berada pada lokasi tertinggi, yaitu pada ketinggian 198 meter dpl. Selain itu, di Dusun Benteng juga terdapat kompleks pemakaman utama yang luasnya mencapai tiga hektar. Sehingga, dapat dikatakan Dusun Benteng sebagai pusat atau awal keberadaan permukiman komunitas Kajang di Desa Tana Toa.

Desa Tana Toa terdiri dari sembilan dusun. Di antara sembilan dusun itu, hanya dua dusun, yaitu Balagana dan Jannayya, yang secara langsung bersentuhan dengan modernitas. Sementara tujuh dusun lainnya (Bo'bu, Benteng, Pangi, Bongkina, Tombolo, Lurayya, dan Balangbina), pada batas-batas tertentu masih setengah terbuka menerima kemajuan zaman. Desa Tana Toa memunyai luas sekira 797 ha. Pada akhir 1980an, Desa Tana Toa sangatlah luas, bahkan mencapai 37 km². Namun, Pak Tayeb, mantan Kepala Desa yang menjabat sejak 1983 s.d 1992, mengajukan usulan pemekaran Tana Toa.
Alhasil, sejak 1993, Desa Tana Toa terpecah menjadi lima desa baru, yaitu Desa Malleleng, Desa Pattiroang, Desa Batu Nilamung, Desa Sapanang, dan Desa Tana Toa sendiri.

Hampir separuh dari luas tersebut, 331,17 ha terdiri dari hutan lebat yang masih terjaga kelestariannya. Secara geografis, Desa Tana Toa bersempadan dengan Desa Bonto Baji di sebelah utara, di sebelah selatan bersempadan dengan Desa Batu Nilamung. Sementara, di sebelah barat dan timur, masing-masing bersempadan dengan Desa Pattiroang dan Desa Malleleng.

Untuk mencapai Tana Toa, dapat ditempuh dengan menggunakan pelbagai transportasi. Dari kota Bulukumba, Desa Tana Toa berjarak sekira $58 \mathrm{~km}$ melalui Tanete, ibukota Kecamatan Bulukumpa, atau tepatnya berada di bagian utara ibukota kabupaten. Dari kota Makassar, untuk mencapai Tana Toa menempuh jarak sekira $250 \mathrm{~km}$, atau waktu perjalanan sekira lima jam. Agar mudah mencapai Tana Toa, sebaiknya kita harus melalui jalur TaneteKassi, yaitu pada pertigaan di Desa Batulohe, tepatnya pada kilometer 14 dari Tanete belok ke kiri. Jalur ini relatif mudah ditempuh karena sarana jalan yang sudah beraspal. Sehingga, kendaraan dapat masuk sampai di pintu gerbang Tana Toa. Satu jalur lagi untuk memasuki Tana Toa, dapat juga ditempuh melalui Desa Malleleng. Tetapi, karena jalan yang hanya sebagian saja yang beraspal, maka jalur ini tidak dapat dilalui oleh kendaraan besar.

Bentang lahan dalam kawasan Tana Toa dapat dibedakan berdasarkan tata guna lahannya, yaitu lahan permukiman, lahan pertanian, lahan peternakan dan hutan adat. Bentuk bentang lahannya merupakan daerah perbukitan dengan tekstur bergelombang lemah, yang pada beberapa tempat merupakan tanah datar dan landai. Kemiringan 
UNISIA, Vol. XXXI No. 70 Desember 2008

permukaan tanah pada beberapa tempat mencapai $45^{\circ}$. Bahkan, di sebelah utara permukiman merupakan tebing terjal mencapai kemiringan $80^{\circ}$ sampai $90^{\circ}$, yang memanjang arah barat-timur dengan titik tertinggi di sebelah barat dan melandai ke arah timur.

Kehidupan orang Kajang di kawasan adat umumnya bertani, yaitu bercocok tanam dan beternak. Mereka sangat memanfaatkan setiap jengkal lahan tanah semaksimal mungkin untuk diolah menjadi lahan pertanian. Sebab, dalam kawasan adat Tana Toa sudah tidak dapat membuka lahan pertanian baru dengan membabat pohon di hutan. Pada dasarnya, semua lahan yang ada dalam kawasan adat Tana Toa merupakan milik adat.

Pernyataan ini disangsikan oleh beberapa informan, yang juga merupakan elite desa di luar Tana Toa. Mereka mengatakan, hampir semua elite yang pernah memimpin Tana Toa, atas restu Ammatoa, sudah mendapat "jatah" pengkaplingan tanah di hutan yang semestinya tidak boleh dibabat. Para mantan elite desa itu mengambil keuntungan pribadi dengan menanami "tanah jatah" itu dengan tanaman komoditi ekspor, seperti cengkeh, cokelat, dan karet.

Dalam istilah lokal, setiap kepala desa, dipanggil dengan sebutan Pak Desa, Ialu diikuti nama desa di belakangnya. Contoh, Kepala Desa Tambangan dipanggil dengan sebutan Pak Desa Tambangan. Begitu pula dengan para kepala desa lainnya, berikut dengan perangkat desanya.

Bagi sesiapa pun yang melanggarnya akan dikenakan sanksi yang diputuskan secara adat. Lahan di dalam kawasan adat Tana Toa tidak bisa digunakan sebagai lahan untuk menanam padi. Selain tidak ada irigasi teknis, secara adat juga tidak memung- kinkan untuk mencetak sawah baru di dalam kawasan tanpa membabat hutan. Jadi, selama ini, masyarakat menanam padi di sawah yang berada di luar kawasan Tana Toa. Hasil pertanian lainnya adalah hasil kebun yang umumnya ditanami jenis tanaman jagung, pisang, kopi, cengkeh, dan sedikit cokelat. Hewan ternak yang umum dibudidayakan adalah jenis unggas (ayam dan itik), sapi, kerbau, dan kuda.

Bagi masyarakat dalam kawasan adat Tana Toa, hutan merupakan elemen ekologi yang sangat penting. Pasang secara eksplisit melarang setiap tindakan yang mengarah pada kemungkinan rusaknya ekosistem hutan, seperti menebang kayu, memburu satwa, atau memungut hasil-hasil hutan. Pasang inilah yang memberikan ketentuan tersebut agar aturan yang ditetapkan berjalan dengan efektif. Konsekuensinya, bagi siapa saja yang melanggar aturan-aturan yang telah ditentukan akan dikenai sanksi yang tegas. Tentang bagaimana usaha agar warga komunitas menaati aturan pelestarian hutan yang berdasarkan atas pasang, maka di bawah kepemimpinan Ammatoa sebagai kepala adat mengadakan acara a'borong (bermusyawarah) yang menetapkan bahwa pelanggaran atas ketentuan pasang yang berhubungan dengan pelestarian hutan dikenakan denda (apabila diketahui pelanggarnya) sebagai berikut: Pertama, cappa ba'bala atau pelanggaran ringan. Cappa ba'bala diberlakukan terhadap pelanggar yang menebang pohon dari koko atau kebun warga masyarakat adat Ammatoa. Hukumannya berupa denda enam real atau menurut mata uang Indonesia kira-kira setara dengan uang enam ratus ribu rupiah. Selain itu, pelanggar juga wajib memberikan satu gulung kain putih kepada Ammatoa. Kedua, tangnga ba'bala atau pelanggaran sedang. Tangnga ba'bala 
merupakan sanksi untuk pelanggaran yang dilakukan dalam kawasan hutan perbatasan atau Borong Batasayya. Pengambilan kayu atau rotan atau apa saja dalam kawasan ini tanpa seizin Ammatoa berarti melanggar aturan tangnga ba'bala. Ketika seseorang diizinkan oleh Ammatoa untuk mengambil sebatang pohon kemudian ternyata mengambil lebih banyak dari yang diizinkan, maka orang tersebut telah melanggar aturan Tangnga ba'bala ini. Denda dari pelanggaran ini sebesar delapan real atau sebanding dengan delapan ratus ribu rupiah dengan mata uang Indonesia ditambah satu gulung kain putih. Ketiga, poko' ba'bala atau pelanggaran berat. Poko' ba'bala diberlakukan kepada seluruh komunitas yang bernaung di bawah kepemimpinan Ammatoa jika melakukan pelanggaran berat menurut adat. Poko' ba'bala diberlakukan jika komunitas adat melakukan pelanggaran di Barong Karamaka atau hutan keramat dalam bentuk mengambil hasil hutan baik kayu maupun nonkayu yang terdapat di dalamnya. Poko' ba'bala merupakan hukuman terberat dalam konsep aturan adat masyarakat Ammatoa. Komunitas adat yang melakukan pelanggaran berat dikenai sanksi berupa denda dua belas real, atau dalam mata uang Indonesia setara dengan satu juta dua ratus ribu rupiah, kain putih satu lembar, dan kayu yang diambil dikembalikan ke dalam hutan. Di samping sanksi berupa denda, hukuman adat yang sangat memengaruhi kelestarian hutan adalah sanksi sosial berupa pengucilan. Hukuman ini bagi komunitas adat Kajang lebih menakutkan. Jika masyarakat melanggar poko' ba'bala maka Ammatoa tidak akan menghadiri setiap acara atau pesta yang dilangsungkannya. Ketika Ammatoa tidak hadir maka setiap acara atau pesta yang berlangsung dianggap sia-sia. Bagi mereka yang telah melanggarnya, lebih baik dipenjara seumur hidup daripada harus terkena poko' ba'bala. Lebih menakutkan lagi karena sanksi pengucilan ini berlaku juga bagi seluruh keluarga sampai tujuh turunan. Apabila sebuah pelanggaran tidak diketahui siapa pelakunya, maka Ammatoa akan melangsungkan upacara attunu panroli (membakar linggis sampai merah karena panasnya). Mendahului upacara tersebut dipukullah gendang di rumah Ammatoa dengan irama tertentu yang langsung diketahui oleh warga komunitas Kajang, bahwa mereka dipanggil berkumpul untuk menghadiri upacara attunu panroli. Kepada setiap warga dipersilakan memegang linggis yang sudah berwarna merah karena panasnya. Bagi orang yang tangannya melepuh ketika memegang linggis itu, maka dialah pelakunya. Sedangkan bagi yang bukan pelaku, tidak akan merasakan panasnya linggis tersebut. Akan tetapi pada umumnya pelaku tidak mau menghadiri upacara tersebut. Sehingga, untuk mengetahui pelakunya (yang mutlak harus dicari), maka diadakan upacara attunu passau (membakar dupa). Mendahului upacara tersebut, terlebih disampaikan pengumuman kepada segenap warga selama sebulan berturut-turut, dengan harapan bahwa pelaku, maupun yang mengetahui perbuatan penebangan pohon itu akan datang melapor kepada Ammatoa. Attunu passau adalah kegiatan menjatuhkan hukuman "in absentia". Hukuman ini dipercaya langsung diberikan oleh Tu Rie' A'ra'na, yang berupa musibah secara beruntun, baik pada pelaku, keluarga, dan keturunannya, serta orang lain yang mengetahui perbuatan itu, namun tidak melaporkannya kepada Ammatoa.

Dengan terpeliharanya hutan, ekosistem di sekitarnya juga dapat berjalan dengan baik. Beberapa vegetasi yang umum tumbuh di kawasan adat Tana Toa di antaranya, jambu mete, nangka, kelapa, 
UNISIA, Vol. XXXI No. 70 Desember 2008

mangga, lontar, rambutan, bambu, enau (aren), sukun, jati, sagu, dan pelbagai jenis kayu hutan yang tumbuh subur di dalam kawasan hutan adat. Kesuburan tanaman dapat dimungkinkan karena sebagian besar lahan memiliki lapisan tanah permukaan yang gembur.

Sebuah etnografi yang disituasikan dalam sebuah perdesaan yang kental nuansa adat seperti di Tana Toa akan merefleksikan keadaan yang lebih baik dari penelitian saya. Saya juga menyadari bahwa dalam komunitas adatlah ada tekanan kebutuhan untuk menengahi tema yang saya usung: budaya, politik dan arus modernitas, ketimbang mencari di desa lain di Kecamatan Kajang yang relatif lebih urban. Bila saya memahami bahwa nilai-nilai adat dan dan kehadiran kekuatan politik seperti partai-partai di desa, menciptakan situasi etnografis yang lebih rumit untuk melakukan analisis. Saya menginsyafi bahwa kompleksitas yang inheren itu sendiri menawarkan keuntungan-keuntungan tertentu. Dalam sebuah lingkungan semacam itu di mana wacana, ideologi, dan kontestasi kepentingan kekuasaan yang dibawa oleh pelbagai pihak, bercampur dengan nilai-nilai adat (acap kali bertentangan satu sama lain) segera dan secara langsung terasakan. Maka, kebutuhan untuk merasakan dan mengintegrasikannya ke dalam kehidupan sehari-hari adalah lebih urgen.

Sistem politik adalah aspek masyarakat atau pun komunitas yang berfungsi untuk mempertahankan hukum dan ketertiban di dalam suatu komunitas, dan untuk mengatur hubungan-hubungan eksternal di antara dan di kalangan komunitas. Sistem politik membangun caracara kontrol sosial dan aturan-aturan yang dirancang untuk membatasi perilaku individu-individu dalam batas-batas tertentu dan untuk membuat serta menjalankan keputusan-keputusan untuk kepentingan seluruh masyarakat. Politik terdapat secara universal dalam komunitas manusia, karena semua komunitas memunyai pelbagai cara pengendalian sosial dan pembuatan keputusan. Akan tetapi, sifat khusus kontrol politik dan pembuatan keputusan berbedabeda di antara komunitas satu dengan yang lainnya. Setiap komunitas memunyai mekanisme sendiri dalam mengawasi dan menjamin bahwa keputusan-keputusan dan rencana-rencana dapat dilaksanakan dengan berhasil, tidak terkecuali komunitas adat di Kajang (Sanderson, 2000:296).

Dalam konteks sistem politik ini, komunitas adat Kajang di Tana Toa dipimpin oleh seorang disebut Ammatoa dan mereka sangat patuh padanya. Kalau Tana Toa berarti tanah yang tertua, maka Ammatoa berarti bapak atau pemimpin tertua. Ammatoa memegang tampuk kepemimpinan di Tana Toa sepanjang hidupnya terhitung sejak dia dinobatkan. Sebabnya proses pemilihan Ammatoa tidak gampang. Adalah sesuatu yang tabu di Tana Toa bila seseorang bercita-cita jadi Ammatoa. Pasalnya, Ammatoa bukan dipilih oleh rakyat, tetapi seseorang yang diyakini mendapat berkah dari Tu Rie'A'ra'na.

Yusuf Akib, peneliti antropologi, dalam buku Potret Manusia Kajang (2003) menuliskan bahwa fungsi dan peran Ammatoa telah bergeser dari pemimpin pemerintahan (dalam skala komunitas) menjadi sekadar pemimpin acara ritual keagamaan. Itu terjadi sejak era pascakemerdekaan, yang diperkuat pada 2-3 dekade terakhir. Alhasil, peran-peran majelis adat untuk membantu Ammatoa mengurusi berbagai bidang pemerintahan skala komunitasnya jadi kerdil. Peran para pembantu Ammatoayang lazim disebut kolehai menjadi tumpul. Kendati begitu, Ammatoa masih berperan 
dalam mekanisme politik tradisional yang berlaku di Kajang.

Selain sebagai pemimpin adat, Ammatoa bertugas sebagai penegak hukum sebagaimana dipesankan dalam pasang ri Kajang. Komunitas adat Kajang menerapkan ketentuan-ketentuan adat dalam kehidupan sehari-hari termasuk dalam pemanfaatan hutan. Ketentuan adat yang diberlakukan di wilayah adat Ammatoa Kajang diberlakukan kepada seluruh komponen komunitas, tanpa kecuali. Ketentuan ini berlandaskan pesan leluhur yang disampaikan secara turuntemurun. Ketentuan adat ini dipandang sebagai sesuatu yang baku (lebba) yang diterapkan kepada setiap orang yang telah melakukan pelanggaran. Dalam hal ini diberlakukan sikap tegas (gattang), dalam arti konsekuen dengan aturan dan pelaksanaannya tanpa ada dispensasi, sebagaimana disebutkan dalam pasang yang berbunyi: 'Anre na'kulle nipinra-pinra punna anu lebba' Artinya : Jika sudah menjadi ketentuan, tidak bisa diubah lagi.

Menurut mitologi orang Kajang, ketika manusia belum banyak menghuni bumi, sebutan Ammatoa belum dikenal. Yang ada ialah Sanro atau Sanro Lohe (dukun yang sakti). Sanro Lohe bukan hanya sekadar sebagai dukun yang dapat mengobati penyakit, melainkan juga tokoh pimpinan dalam upacara ritual keagamaan sekaligus sebagai pemimpin kelompok. Selepas manusia kian ramai dan kebutuhan semakin berkembang sesuai dengan tuntutan zaman, istilah Amma mulai dikenal. Struktur organisasi pun dibentuk dengan pembagian tugas dan fungsi masing-masing. Pembagian kekuasaan ini termaktub dalam pasang ri Kajang: Amma mana' ada' (Amma melahirkan adat) dan Amma mana' karaeng (Amma melahirkan pemerintahan).

Ammatoa didampingi dua orang Anrong (ibu) masing-masing Anrongta ri Pangidan
Anrongta ri Bongkina dan para pemangku adat. Anrongta ri Pangi bertugas melantik Ammatoa. Selain itu, dalam sistem politik tradisional yang berlaku di Kajang, Ammatoa juga dibantu oleh yang disebut sebagai Ada' Lima Karaeng Tallu. Ada' Lima (ri Loheya dan ri Kaseseya) adalah pembantu Ammatoa yang khusus bertugas mengurusi adat (ada' pallabakki cidong). Di antaranya, mereka bergelar Galla Puto yang bertugas sebagai juru bicara Ammatoa, dan Galla Lombo' yang bertugas untuk urusan pemerintahan luar dan dalam kawasan (selalu dijabat oleh Kepala Desa Tana Toa). Selain itu ada Galla Kajang yang mengurusi masalah ritual keagamaan, Galla Pantama untuk urusan pertanian, dan Galla Meleleng untuk urusan perikanan. Setiap pemangku adat memunyai tugas dan kewenangan berbeda-beda. Sementara Karaeng Tallu bertugas membantu dalam bidang penyelenggaraan pemerintahan (ada' tanayya). Pranata adat istiadat dikerdilkan oleh nasionalisasi struktur pemerintahan. Tidak satu pun wilayah dan komunitas di Tanah Air ini yang bebas dari relasi dan intervensi kekuasaan pemerintah, termasuk kawasan adat Tana Toa. Kedaulatan adat yang mestinya diperankan oleh pranata lokal tidak lagi utuh. Bahkan, pada aspek tertentu jadi ambigu. Seorang kepala desa dan camat dengan sendirinya ditempatkan sebagai pemimpin pemerintahan sekaligus pemimpin adat. Labbiria, misalnya, dijabat oleh Camat Kajang, Karaeng Moncongbuloa oleh Kepala Desa Tambangan.

Karaeng Tallu merupakan tri tunggal dalam pemerintahan, dan dikenal dengan "tallu karaeng mingka se'reji". Yang berarti bahwa apabila salah satu di antaranya telah hadir dalam upacara adat, maka Karaeng Tallu sudah dianggap hadir.

Dalam perkembangannya, kendati Ammatoa adalah orang tertinggi dalam 
UNISIA, Vol. XXXI No. 70 Desember 2008

struktur pemerintahan Tana Toa, keberadaan pemerintah di luar kawasan adat tetap diakui. Bahkan karena dianggap lebih berpendidikan, pemerintah di luar Tana Toa juga sangat dihormati. Pemerintah dalam hal ini adalah camat, bupati, dan seterusnya. Bukti penghormatan ini terlihat dalam upacara adat atau sebuah pertemuan di mana pejabat pemerintah mendapat kappara dengan jumlah piring lebih banyak dari Ammatoa. Kappara adalah baki yang berisi sejumlah piring dengan beragam makanan. Dengan kappara ini pula kedudukan seseorang akan terlihat karena semakin besar sebuah kappara atau makin banyak piringnya, maka makin tinggi kedudukannya.

Bila seorang Ammatoa meninggal (a'linrung), majelis adat menunjuk pejabat sementara yang memiliki kualitas yang tidak jauh berbeda dengan Ammatoa. Jabatan sementara dijabat selama tiga tahun. Selepas masa tersebut, tepat pada malam bulan purnama (bangngi kentarang) dilaksanakan appa'runtu pa'nganro, yaitu ritual memanjatkan doa bersama yang dilakukan seluruh komunitas adat Kajang, Kabupaten Bulukumba, untuk memohon keselamatan kepada Yang Maha Kuasa (Tu Rie' A'ra'na). Pelaksanaan ritual ini tidak memiliki waktu pasti. Ritual ini dilaksanakan jika Ammatoa menganggap perlu memohon keselamatan dan terhindar dari bahaya. Ritual ini bisa juga dilaksanakan bila ada warga setempat yang ingin melepas nazar karena terhindar dari suatu bahaya. Tetapi, pelaksanaannya tetap atas izin Ammatoa. Waktu pelaksanaannya pun ditentukan Ammatoa. Menjelang prosesi pemilihan Ammatoa, jika Ammatoa sebelumnya telah mangkat, ritual ini juga terlebih dulu dilaksanakan. Tujuannya, untuk memohon petunjuk Yang Kuasa dan meminta dijauhkan dari segala bahaya dan bencana yaitu upacara ritual anyuru' borong, memohon petunjuk Tu Rie' A'ra'na untuk memilih Ammatoa yang baru. Para calon Ammatoa ini biasanya harus tahu betul adat istiadat di Tana Toa. Selain itu mereka harus bisa menjelaskan asal-usul manusia secara rinci di Tana Toa sejak yang pertama. Ini tentu saja bukan hal mudah dilakukan dan diyakini masyarakat memang hanya orang tertentu yang bisa melakukannya. Pasalnya, di Tana Toa, tabu membicarakan asal-usul manusia bahkan tentang keturunan seseorang.

Dikisahkan Pak Sekdes Tana Toa, setiap kali penobatan Ammatoa dilakukan, seekor ayam jantan dilepas. "Kalau sudah tiba saatnya, atau sudah tiga tahun, para calon dikumpulkan dan ayam yang sudah dilepas saat penobatan terdahulu, "didatangkan" lagi. Di mana ayam itu bertengger maka, dialah yang jadi Ammatoa. Biasanya setelah ayam bertengger wajah orang tersebut langsung berubah-ubah dan sangat bercahaya. Setelah itu ayamnya langsung mati," jelas Pak Sekdes.

\section{Pembahasan}

Hari itu, Sabtu siang 18 Agustus 2007, belasan warga komunitas adat Kajang, dipimpin salah seorang anak kandung Puto Palasa dan tokoh pemuda Kajang, mendatangi rumah jabatan Wakil Bupati Bulukumba. Kedatangan mereka untuk mengadukan anggota kelompok Puto Bekkong yang memanen sawah adat, yang terdapat dalam kawasan adat Kajang di Desa Tambangan, Kecamatan Kajang. Padahal, dalam musyawarah antara Puto Palasa dan Puto Bekkong yang dihadiri seluruh pemangku adat Kajang dan difasilitasi oleh Bupati Bulukumba serta unsur muspida, April 2007 silam, diputuskan bahwa untuk sementara waktu pengelolaan dan penggunaan harta adat, termasuk sawah itu, dalam penguasaan pemerintah kecamatan. 
Menurut warga yang mengadu, apa yang dilakukan anggota kelompok Puto Bekkong melanggar kesepakatan hasil musyawarah. Hal itu menimbulkan kemarahan warga Kajang dari kelompok Puto Palasa. "Kami datang menemui wakil bupati untuk meminta saran dan solusi, karena ingin menyelesaikan masalah ini secara baik-baik," ujar tokoh pemuda Kajang itu, seperti dikatakan Kabag Kesbang Bulukumba, usai mendampingi Wakil Bupati menerima keluhan warga tersebut. Menurut
Kabag Kesbang, masalah itu telah diselesaikan pada 20 Agustus 2007, melalui rapat tripika Kecamatan Kajang. Wakil Bupati memerintahkan Camat Kajang untuk memfasilitasi pertemuan tripika dan mencari solusi.

Perseteruan antara Puto Palasa dan Puto Bekkong sudah berlangsung sejak beberapa tahun Ialu. Dalam prosesi pemilihan Ammatoa, keduanya sama-sama mengaku sebagai Ammatoayang mendapat restu. Keduanya sama-sama memiliki

\section{Struktur Kekuasaan Komunitas Adat Kajang}

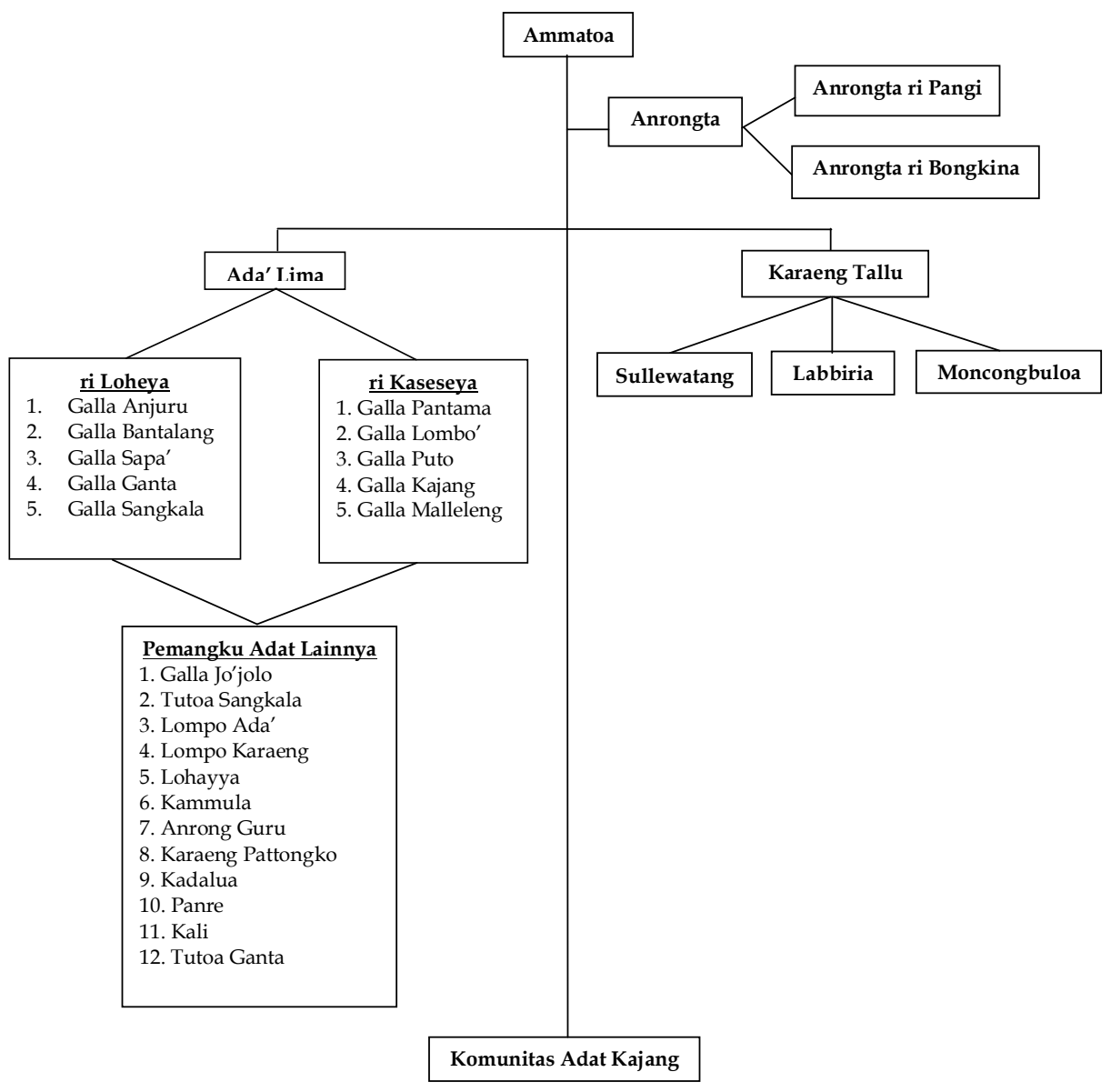


UNISIA, Vol. XXXI No. 70 Desember 2008

pendukung. Dualisme kepemimpinan inilah yang menimbulkan perseteruan warga, termasuk pengelolaan harta adat. Selama perseteruan ini, beberapa kali terjadi insiden yang nyaris menimbulkan bentrok di antara kedua kelompok. April 2007, pemerintah setempat dipimpin Bupati Bulukumba, memfasilitasi pertemuan Puto Palasa dan Puto Bekkong serta seluruh pemangku adat Kajang untuk menyelesaikan dualisme kepemimpinan. Salah satu keputusan dalam pertemuan itu adalah pengelolaan dan penggunaan harta adat untuk sementara dikuasai pemerintah kecamatan hingga ada keputusan pasti. Dalam pertemuan itu, Puto Bekkong sudah mengalah dan mengakui Puto Palasa sebagai Ammatoa. Mayoritas pemangku adat juga sudah mengakui Puto Palasa. Tetapi, masih ada juga pemangku adat yang belum mau mengakui Puto Palasa.

Persengketaan sawah itu hanyalah sebagian kecil dari permasalahan yang ditimbulkan oleh adanya dualisme Ammatoa. Warga komunitas dan para pemangku adat kerap merasa gamang dalam menghadapi dan menyelesaikan permasalahan adat. Sebab, seperti yang telah saya uraikan pada bagian awal tulisan ini, Ammatoa sebagai orang yang dipandang sebagai pemimpin dan hakim dalam memutuskan perkara yang berhubungan dengan adat, dijabat oleh dua orang yang berbeda, Puto Palasa dan Puto Bekkong.

Menurut Akib (2003:13), sejak komunitas adat Kajang berdiri, Ammatoa sudah dijabat oleh 13 orang. Ammatoa terakhir dijabat oleh Puto Nyonyo, ayah kandung Puto Palasa. Meninggalnya Ammatoa tidak serta-merta dilakukan pemilihan Ammatoa yang baru. Untuk sementara, berdasarkan kesepakatan para pemangku adat, "caretaker" Ammatoa disandang oleh Puto Palasa. Selama tiga tahun masa tenggat persiapan pelantikan Ammatoa yang baru, Puto Palasa melaksanakan tugas dan fungsi keseharian Ammatoa. Meski menjabat sebagai pelaksana tugas (PIt) Ammatoa, tidak selalunya PIt otomatis menjadi Ammatoa. Sebab, ada beberapa persyaratan yang mesti dipenuhi oleh seseorang, sesuai dengan pasang. Dan, menurut para informan, selama ini, yang menjadi Ammatoa adalah orang yang sudah sepuh, dan tidak pernah keluar dari Tana Toa. Sementara, Puto Palasa, sejak masa mudanya kerap bepergian keluar Tana Toa untuk mencari nafkah. Puto Palasa juga dianggap sebagai Ammatoa termuda (60) sepanjang sejarah Kajang. Berbeda dengan Puto Bekkong yang sudah sangat uzur (80) dan tidak pernah keluar dari Tana Toa sepanjang hayatnya.

Meski menjabat sebagai pelaksana tugas (PIt) Ammatoa, tidak selalunya Plt otomatis menjadi Ammatoa. Sebab, ada beberapa persyaratan yang mesti dipenuhi oleh seseorang, sesuai dengan pasang. Dan, menurut para informan, selama ini, yang menjadi Ammatoa adalah orang yang sudah sepuh, dan tidak pernah keluar dari Tana Toa. Sementara, Puto Palasa, sejak masa mudanya kerap bepergian keluar Tana Toa untuk mencari nafkah. Puto Palasa juga dianggap sebagai Ammatoa termuda (60) sepanjang sejarah Kajang. Berbeda dengan Puto Bekkong yang sudah sangat uzur (80) dan tidak pernah keluar dari Tana Toa sepanjang hayatnya.

Pertanyaannya, mengapa sampai muncul dua Ammatoa? Padahal, sejak awal mula kehidupan di Kajang, tidak pernah ada kasus munculnya dualisme Ammatoa. Faktor apa yang menjadi pemicunya? Pertanyaan itu menggelayut dalam pikiran saya. Niat awal untuk memotret fenomena politik identitas, sesuai dengan ancangan penelitian saya, berubah ketika saya mengetahui realitas itu. Awalnya, saya 
sangat kesulitan untuk menggali informasi tentang dualisme itu. Hampir semua orang bungkam ketika saya memulai untuk membincangkannya. Saya tidak tahu, apakah para informan saya itu takut mengemukakan fakta sebenarnya, merasa bosan membahasnya karena terlalu sering dibincangkan, atau mereka sengaja menutup cerita yang sebenarnya karena dianggap sebagai sebuah aib tentang komunitas mereka. Bahkan, Galla Lombo', Kepala Desa Tana Toa, tempat saya tinggal selama di Kajang, diam seribu bahasa ketika saya ajak berdiskusi tentang dualisme itu. Belakangan baru saya tahu, kalau Galla Lombo' adalah mantan Sekretaris Desa Tana Toa, dan bawahan langsung Pak Dewan, yang kala itu sebagai Kepala Desa Tana Toa. Beliau tahu persis keterlibatan Pak Dewan dalam dualisme Ammatoa. Dulu, hubungan keduanya begitu rapat. Boleh dikatakan, Galla Lombo'adalah kadernya Pak Dewan. Akan tetapi, pada pemilihan Kepala Desa Tana Toa tahun 2005, keduanya pecah kongsi. Galla Lombo' berhasil memenangkan kursi Kepala Desa Tana Toa, mengalahkan adik kandung Pak Dewan. Sampai tulisan ini dibuat, hubungan keduanya tidak harmonis.

Selama itu, saya tidak mendapatkan informasi yang berarti tentang dualisme Ammatoa. Akhirnya, saya memutuskan untuk keluar sejenak dari Tana Toa.

Saya berusaha mencerap pelbagai informasi di luar Tana Toa, tidak jarang saya menginap di Desa Pattiroang atau di Desa Tambangan untuk sekadar berkenalan dan mencari informan yang saya anggap mengetahui persoalan tersebut. Perkenalan saya dengan Pak Desa Sapanang dan Pak Desa Pattiroang di Desa Pattiroang, memberikan nafas segar dalam penelitian saya, yang sempat mandeg karena tidak mendapatkan informasi yang berarti di Tana Toa. Pada satu malam yang dingin di kediaman Pak Desa Pattiroang, Pak Desa Sapanang bercerita dengan gamblang.

Hari itu dini hari pertengahan Maret 2003. Saya lupa tanggal persisnya kapan. Kami mengadakan pa'nganro untuk memilih Ammatoa yang baru. Saat itu, calon Ammatoa hanya dua orang, Puto Bekkong dan Puto Palasa. Prosesi acara berlangsung tiga hari tiga malam. Saya mengikuti semua rangkaian acara bersama beberapa kepala desa yang lain. Sepanjang umur saya, baru kali ini saya mengikuti pa'nganro. Tidak sembarang orang diperkenankan mengikuti prosesi sakral itu. Kalau tidak cukup "ilmu", tidak bisa ikut. Kalau memaksakan ikut, biasanya sepulang dari acara pa'nganro, yang bersangkutan bisa meninggal, atau minimal gila. Suasana pa'nganro memang lain. Sangat khidmat dan penuh mistik. Pemilihan Ammatoa, dilakukan di dalam hutan (pa'rasangang i lau') berlangsung pada malam ketiga. Saya merasakan hal yang janggal pada malam itu. Orang-orang berkumpul secara berkelompok terpisah satu dengan lainnya. Padahal, pada malammalam sebelumnya berbaur saja. Saya dan beberapa kepala desa lainnya, menepi di sudut lapangan pertemuan. Saya makan sedikit dan minum, karena lapar dan haus. Saat makan dan minum itu, saya memperhatikan, Pak Dewan hilir mudik dan sesekali berbicara serius dengan seseorang, nadanya sangat pelan. Pemandangan itu saya lihat berkali-kali. Orang yang berbicara dengan Pak Dewan terlihat tegang setiap kali melaporkan sesuatu kepada Pak Dewan. Setelah melapor, ia kembali lagi ke kerumunan massa yang mengikuti prosesi. Selepas makan dan minum, kami kembali ke tengah lapang untuk mengikuti prosesi. Singkat cerita, pada rangkaian puncak pemilihan, Anrongta ri Pangi memberikan 
UNISIA, Vol. XXXI No. 70 Desember 2008

pa'mamang yaitu semacam piring yang diisi dengan sesaji khusus, diberikan kepada seseorang sebagai penghormatan kepada Puto Bekkong.

Menurut aturan adat, barang siapa yang diberikan pa'mamang oleh Anrongta ri Pangi, maka dialah yang berhak melanjutkan prosesi pengambilan sumpah sebagai Ammatoa. Namun, ketika Anrongta ri Pangi memberikan pa'mamang kepada Puto Bekkong, Puto Palasa berdiri dan berkata, "Kenapa bukan saya yang diberikan pa'mamang? Bukankah saya adalah pejabat Ammatoa. Nupakasiri'ka punna teai nakke anjari Ammatoa (kamu bikin malu saya kalau bukan saya yang terpilih sebagai Ammatoa)," ujar Puto Palasa dengan suara yang lantang sembari mengambil parang, diikuti pengikutnya. Mendapati hal itu, Anrongta ri Pangi bersikukuh dengan pendiriannya. Tetapi Puto Palasa terus mendesak seraya mengancam akan terjadi pertumpahan darah pada malam itu, andaikata bukan dia yang terpilih sebagai Ammatoa. Akhirnya, dengan penuh kesabaran, Puto Bekkong, yang juga paman Puto Palasa, mengalah. "Kalau itu memang maumu, saya mengalah. Silakan kamu saja yang menjadi Ammatoa. Saya tidak mau ada perpecahan dan pertumpahan darah di antara kita," kata Puto Bekkong. Anrongta ri Pangitidak bisa berbuat apa-apa, menuruti semua kehendak Puto Palasa. Pak Dewan yang berada di samping saya menyunggingkan seulas senyum. Mimiknya terlihat senang karena Puto Palasa yang terpilih sebagai Ammatoa.

Apa yang diceritakan kedua informan saya itu, bukanlah isapan jempol semata. Beberapa informan yang lain juga mengafirmasi cerita itu. Pak Syamsuddin, informan saya yang lain, juga mengatakan hal yang sama. Pak Syamsuddin adalah salah satu penyandang dana upacara pa'nganro tersebut. Upacara pa'nganro selalu dibarengi dan didanai oleh orang yang memiliki hajat. Biasanya disokong oleh lebih dari dua orang. Hajat orang tersebut bermacam-macam. Biasanya untuk mensyukuri dari lepasnya marabahaya atau menunaikan nazar.

Jadi beliau mengikuti rangkaian acara tersebut dari awal sampai akhir. Menurutnya, salah satu alasan Puto Bekkong mengalah, selain alasan yang uraikan di atas, adalah untuk menyelamatkan upacara pa'nganro agar tidak sampai gagal. Sebab, kasihan para penyokong dana yang sudah menghabiskan dana yang tidak sedikit, sekira ratusan juta rupiah.

Mengalahnya Puto Bekkong, tidak serta merta menyelesaikan pertentangan di antara keduanya. Para pendukung Puto Bekkong, tidak mau terima dengan terpilihnya Puto Palasa sebagai Ammatoa. Sebenarnya, kalau pelantikan Ammatoaitu seperti demokrasi yang lazim dipraktikkan banyak orang dengan menggunakan suara terbanyak, tentu Puto Bekkonglah yang menjadi Ammatoa. Sebab, massa beliau lebih banyak, tersebar di pelbagai desa di Kecamatan Kajang. Tetapi, pelantikan Ammatoa tidak seperti pemilihan kepala desa.

Penjelasan para informan saya tentang dualisme Ammatoa, selalu mengaitkannya dengan peran sentral Pak Dewan. Siapa Pak Dewan sebenarnya? Bagaimana sepak terjang dia selama ini? Pertanyaan itu, kembali memaksa saya untuk terus menelusuri informasi yang beredar tentang dia.

Pak Dewan adalah anggota legislatif dari Partai Syarikat Indonesia (PSI), ia meraih kursi legislatif itu pada 2004 lalu. Perawakannya tinggi besar, berkumis, dan lantang dalam berbicara. Sepintas, ia terlihat sangat cerdas di antara orang Kajang pada 
umumnya. Ketika saya menyambangi kediamannya di depan Pasar Kajapoa, ia terlihat santai menerima tetamu. Saya perhatikan, mereka sedang berbincang serius. Pikir saya, dia sedang konsolidasi dengan tim suksesnya, maklum menjelang pemilu. Pembicaraan saya dengannya merangkum pelbagai hal tentang Kajang dan perpolitikan yang melingkupinya. Beberapa pokok pikiran dan gaya bicaranya tinggi, saya menilai ia adalah sosok yang ambisius dalam politik. Tidak banyak hal kontroversial tentang Kajang yang keluar dari mulutnya. Bahkan, ketika ditanya soal dualisme Ammatoa, ia terkesan menutupi dan cenderung menyalahkan Puto Bekkong yang dianggapnya kemaruk dalam kekuasaan.

Penjelasan tentang Pak Dewan saya dapatkan dari orang-orang terdekatnya, baik yang sejalan atau pun yang berseberangan dengannya. Salah satu penjelasan yang cukup valid dan andal, saya dapatkan dari mantan Galla Lombo', salah seorang peneroka dan sesepuh orang Kajang. Ditemani secangkir teh dan rokok kretek yang asapnya terus mengepul, mantan Galla Lombo' itu menuturkan kisahnya.

Saya mengenal Pak Dewan sudah sejak lama. Sejak saya menjadi kepala desa di Tana Toa pada 1983. Saat itu, Pak Dewan masih remaja. Dia nakal, seperti umumnya remaja kebanyakan. Tetapi dia cerdas, meski terkesan arogan dan ambisius. Dia kuliah di Fakultas Teknik Unhas, tetapi tidak selesai. Karena aktif di organisasi. Kuliahnya tidak jelas, berantakan. Kesan saya terhadap dia biasa saja, selama tiga tahun awal pemerintahan saya di Tana Toa. Sampai akhirnya, satu peristiwa yang tidak bisa saya lupakan terjadi pada 1986. Saat itu, massa mengepung rumah saya dan melemparinya dengan batu. Massa mengamuk dengan membabi buta. Malam itu, saya berhadapan dengan Pak Dewan dan temannya yang masuk ke rumah saya dengan membawa sebilah parang. Tetapi, dia tidak membacok saya. Padahal, saya sudah berhadapan dengannya dan saya dalam keadaan terjepit. Saya difitnah olehnya. Dikatakan, saya akan merusak adat dengan memindahkan kalompoang, semacam keris pusaka. Belakangan baru saya tahu kalau sebenarnya Pak Dewan tidak suka saya menjadi kepala desa, dan dia ingin menggantikan saya. Akhirnya dia menghasut massa dan Ammatoa, Puto Cacong, untuk menentang saya. Selain itu, ada juga hal lain yang melatarbelakangi peristiwa itu. Sebelumnya, saya dipanggil Ammatoa. Ammatoa menyuruh saya memanggil bupati agar segera datang ke Kajang. Waktu itu, Ammatoa mempunyai calon untuk menduduki posisi Camat Kajang. Padahal, calon yang didukung Ammatoa itu bukanlah keturunan Labbiria. Atas dasar itu, saya selalu bilang pada Ammatoa, bahwa Pak Bupati sedang sibuk, jadi tidak bisa datang ke Kajang. Berkali-kali saya diingatkan soal ini, tetapi saya tetap tidak mau menyampaikan kepada Pak Bupati. Penolakan halus saya itu dimanfaatkan oleh Pak Dewan untuk menjelek-jelekkan saya. Dia mengatakan, bahwa saya sengaja untuk tidak memanggil bupati datang ke Kajang. Akhirnya, atas hasutan Pak Dewan, dikatakan kepada Ammatoa, "Kalau Ammatoa ingin Pak Bupati datang ke Kajang, pasang saja gambar Ka'bah di rumah Amma. Niscaya, Pak Bupati segera datang." Saat itu, Pak Dewan menghubungi salah seorang anggota DPRD Bulukumba untuk datang bertemu Ammatoa. Betapa kagetnya anggota dewan itu, ketika melihat gambar Ka'bah yang cukup besar terpampang di dalam rumah Ammatoa. la mengira, Ammatoa sudah berpihak kepada Partai 
UNISIA, Vol. XXXI No. 70 Desember 2008

Persatuan Pembangunan (PPP). Padahal, saat itu, kekuatan Orde Baru dengan Golkarnya, begitu massif di seluruh pelosok negeri ini. Mengetahui hal itu, akhirnya bupati datang ke Kajang dan melihat sendiri gambar Ka'bah itu. Betapa terkejutnya bupati. Impaknya saya dimarahi habishabisan oleh Pak Bupati. Saya dianggap tidak becus memimpin Tana Toa dan mengamankan basis suara Golkar di sana. Pak Dewan memang hebat dalam berpolitik.

Lebih lanjut mantan Galla Lombo' menguraikan, setelah peristiwa itu Pak Dewan menghilang beberapa bulan. Bahkan ia menjadi buronan polisi. Disinyalir, ia bersembunyi di Makassar. Sampai satu hari ia kembali ke Tana Toa, dan semuanya berlalu tanpa ia merasa bersalah sedikitpun. Peristiwa itu ditutup dengan "perdamaian" di antara pihak yang berselisih. Mantan Galla Lombo'kembali memimpin Tana Toa sampai akhir masa jabatannya pada 1992.

Penjelasan mantan Galla Lombo' mengernyitkan dahi saya, seraya mencoba meraba-raba keterkaitan satu peristiwa dengan peristiwa lainnya, berikut dengan para tokoh yang ikut berperan di dalamnya. Keterlibatan Pak Dewan yang berusaha mendongkel kepemimpinan mantan Galla Lombo', campur tangan Ammatoa dalam penempatan seorang camat di Kajang yang bukan keturunan Labbiria, menjadi catatan khusus saya dalam menelusuri informasi tentang akar munculnya dualisme dan perselingkuhan politik Ammatoa.

Dewi fortuna menyertai perjalanan waktu Pak Dewan. Pada 1993 s.d 2001 ia menjadi Kepala Desa Tana Tona, mengalahkan menantu mantan Galla Lombo'. Pak Dewan kembali menjadi kepala desa untuk periode berikutnya 2001-2006. Namun, pada masa itu, Pak Dewan tidak merampungkan masa jabatannya. Angin reformasi dan keterbukaan politik menggodanya untuk membidik jabatan yang lebih prestisius ketimbang sekadar menjadi kepala desa-anggota legislatif Kabupaten Bulukumba. Sebagai pembuka jalan, pada 2003 ia masuk dan memimpin Partai Syarikat Indonesia di Bulukumba.

Para informan saya mengatakan, 2003 adalah awal karut-marutnya adat di Kajang, ditandai dengan masuknya Pak Dewan sebagai caleg, dan pemilihan Ammatoa yang baru. Ada pertalian politik yang kuat antara Pak Dewan yang ingin menjadi anggota dewan dan Puto Palasa yang mencalonkan diri sebagai Ammatoa. Simbiosis mutualisme berlangsung di antara keduanya. Pada 2003 penggalangan massa dan kampanye pemilu sudah marak. Semua caleg di Kajang mulai menjaring massa, membuat citra, dan menarik simpati dan dukungan para pemuka adat, tidak terkecuali Pak Dewan. Hampir semua tahu, Pak Dewan begitu rapat dengan Puto Palasa. Gelar Galla Lombo'yang disandangnya sebagai Kades Tana Toa, semakin mempermudah interaksinya dengan Puto Palasa, yang kala itu menjadi "caretaker" Ammatoa. Para caleg dan partai politik yang lain tidak mampu masuk di Tana Toa dan mendekati Puto Palasa. Tana Toa sudah dikuasai Pak Dewan dan PSI-nya. Sekadar diketahui, wajib pilih di Tana Toa pada waktu itu, sudah mencapai 2.000 orang. Sementara harga kursi di DPRD Bulukumba cuma 3.000 suara. Artinya, dengan menguasai Tana Toa saja, separo harga kursi, sudah bisa dipegang.

Dan akhirnya, Pak Dewan berhasil mendapatkan kursi legislatif yang dia idamkan. Sebagai imbalannya, Pak Dewan begitu gigih mempertahankan dan membela Puto Palasa, ketika Puto Palasa digugat oleh pelbagai pihak berkait dengan dualisme Ammatoa. Begitu pula dengan Puto Palasa, ia sangat berkepentingan memperjuangkan 
Pak Dewan agar terpilih sebagai anggota dewan, agar otoritasnya sebagai Ammatoa tidak diganggu gugat oleh para pihak, terutama pemerintah daerah yang sempat turut campur dalam menyelesaikan persengketaannya dengan Puto Bekkong.

Kolaborasi keduanya tampak pula pada pemilihan Gubernur Sulsel 2007 Ialu. Pasangan Aziz Pak Dewan Muzakkar-Mubyl Hamdalin yang didukung oleh PSI berhasil menang mutlak di Tana Toa. Padahal, menurut logika politik, rasanya tidak masuk akal pasangan Aziz-Mubyl bisa memenangkan suara mutlak orang Tana Toa. Sebab, latar belakang sejarah ayah Aziz, Pak Dewan Muzakkar, sangatlah kelam di Kajang.Saat Pak Dewan Muzakkar menguasai Sulawesi Selatan, orang Kajang dikafir-kafirkan. Mereka mendapat perlakuan tidak ramah. Suatu ketika, pasukan Pak Dewan Muzakkar tiba-tiba datang dengan parang dan pedang, mereka membunuh dan membakar rumah warga. Mereka meradang ketika melihat penduduk-penduduk desa di Tana Toa tidak mau tunduk menjalankan syariat Islam dan bayar upeti. Itu artinya, Pak Dewan dan Ammatoa berhasil memobilisasi warga Tana Toa dan melekangkan sejarah hitam Pak Dewan Muzakkar dalam benak orang Kajang.

Drama perselingkuhan politik Pak Dewan dan Puto Palasa berimpak fatal pada implementasi pasang dalam kehidupan orang Kajang. Adat istiadat yang dulu begitu kokoh dipegang, sekarang semakin pudar. Salah satunya ditandai dengan surutnya pesan a'lemo sibatang, a'bulo sipappa', tallang sipolua, manyu siparampe, sipakatau tang sipakasiri yang artinya memupuk kesatuan dan persatuan dengan penuh kekeluargaan dan saling memuliakan. Para pendukung di antara kedua kubu, saling berseteru sampai sekarang. Kasus perebutan sawah seperti yang saya kemukakan di atas, adalah salah satu dampak pudarnya adat. Selain itu pula, kerap kali setiap pelanggaran yang dilakukan oleh orang luar atau pun orang dalam adat Kajang sendiri, begitu sukar untuk diadili secara hukum adat. Sebagai contoh, seorang warga komunitas menebang pohon di luar batas toleransi yang dibenarkan. Warga yang bersalah itu mencari pembenaran di salah satu Ammatoa. Kalau Puto Palasa mengatakan ia bersalah, maka yang bersangkutan lari ke pihak Puto Bekkong untuk meminta perlindungan hukum, begitu pun sebaliknya.

Hal lain yang memudarkan adat dan menjadi impak atas dualisme Ammatoa, adalah munculnya dualisme di antara pemuka adat yang lain. Kedua belah pihak, membentuk struktur kekuasaannya masingmasing. Akhirnya, tidak heran kalau Galla Puto ada dua orang, Galla Pantama, Galla Kajang, dan begitu juga Anrong Gurua. Semuanya menjadi dualisme. Padahal, ketika salah seorang warga atau lebih ingin membuat hajatan dengan upacara adat, dan mesti mengundang para pemangku adat, lalu pemangku adat dari pihak mana yang mesti diundang. Ketika hal ini saya tanyakan kepada warga komunitas, mereka menggelengkan kepala, bingung, dan diam tidak mengerti.

Saat hari-hari terakhir keberadaan saya di Kajang, saya berkesempatan menghadiri upacara adat pa'dangangngang, yaitu upacara memperingati seratus hari meninggalnya Anrongta ri Pangi. Begitu banyak warga yang menghadiri. Dengan berbisik, Pak Desa Pattiroang berkata kepada saya, "Orang yang hadir di sini, semuanya pendukung Puto Bekkong." Saya hanya mengangguk-angguk, tidak memberikan komentar. Pantas saja, sedari tadi para tetangga Puto Palasa yang saya kenal tidak tampak di antara hadirin yang lain. Saya duduk di pojok ruangan rumah Anrongta ri 
UNISIA, Vol. XXXI No. 70 Desember 2008

Pangi, sembari memotret rangkaian prosesi dan menyimak pembicaraan tetamu, yang sedikit-sedikit saya pahami. Para tamu mendiskusikan, kira-kira siapa yang akan menjadi pengganti Anrongta ri Pangi. Pertanyaan ini sangat sukar untuk dijawab. Sebab, yang berhak melantik Anrongta ri Pangi yang baru adalah Ammatoa. Lalu, pertanyaannya, Ammatoa yang mana berhak melantik. Sementara, warga yang hadir untuk memberikan kesepakatan, mayoritas adalah pendukung Puto Bekkong. Dan, memang, katanya, secara kuantitas, pendukung Puto Bekkong jauh lebih banyak ketimbang pendukung Puto Palasa.

Untuk membincangkan permainan politik di Kajang, ada baiknya kita menyimak ulasan Adrian Leftwich (1983) yang memberikan satu skop pemahaman yang sangat luas tentang politik dalam hubunganhubungan sosial di masyarakat. la menyatakan, proses politik ada di mana-mana, melibatkan siapa saja, apakah itu satu suku bangsa terasing di pedalaman Afrika ataupun calon yang bertanding untuk memperebutkan kursi Presiden di Gedung Putih (White House). Masyarakat awam tanpa membedakan jenis kelamin, umur, dan tingkat pendidikan, sesungguhnya juga terlibat dalam proses politik itu, meski tidak banyak orang yang menyadari keterlibatan mereka. Interaksi dengan rekan sejawat di kantor (dyadic), misalnya, hal itu sudah bisa dikatakan adanya hubungan politik, terlebih lagi seandainya hal itu berlaku di dalam sebuah partai politik (Leftwich: 2004)

Dengan mengemukakan beberapa contoh empirik yang ada di dalam sekelompok suku Maasai di Afrika; suku Kung San di kawasan Kalahari, selatan benua Afrika; masyarakat Aztech di Mexico; perebutan jabatan tertentu di tingkat universitas maupun di dalam Bank Dunia sekalipun, Leftwich (1983: 11) menjelaskan:
"Politics consists of all the activities of cooperation and conflict, within and between societies, whereby the human species goes about obtaining, using producing and distributing resources in the course of the production and reproduction of its social and biological life. These activities are not isolated from othe features of social life. They everywhere influence, and are influenced by, the distribution of power and decision-making, the systems of social organization, culture and ideology in a society, as well as its relations with the natural environment and other societies. Politics is therefore a defining characteristic of all human groups, and always has been".

Makna politik bagi Leftwich adalah lebih luas karena hal itu menitikberatkan kepada unsur politik yang sesungguhnya terdapat di dalam masyarakat, dan hal itu tidak hanya terfokus kepada persoalan institusi pemerintahan. la berpendapat, politik ada pada setiap tingkat aktivitas dan di dalam setiap lapangan yang melibatkan bagaimana "sumber-sumber" digunakan, dihasilkan, diatur, dan didistribusikan, serta oleh siapa saja dan apa saja akibat yang ditimbulkan. Sumber-sumber yang dimaksudkan tidak saja modal, tanah, pendapatan, buruh, tetapi juga sumber-sumber alam seperti sungai dan laut. Dalam pendistribusian ini, praktik politik tetap ada walaupun pada tingkat masyarakat awam, kalangan petani, penduduk kampung atau pegawai pemerintah.

Tampak dalam perhatian Leftwich adanya faktor "sumber" sebagai sesuatu yang sangat penting dan hal itu tidak hanya bersifat kebendaan (material), tetapi juga yang bersifat bukan kebendaan. Apatah lagi yang lebih penting ialah "sumber" tersebut tidak pernah mencukupi dan selalu menjadi objek persaingan. Oleh itu, dalam persaingan itulah praktik politik sukar dielak- 


\section{Perselingkuhan Politik Ammatoa...; Moh Ilham A Hamudy}

kan, apakah dalam kelompok, organisasi, masyarakat, atau pun negara.

Lazimnya, perhatian politik hanya bertumpu kepada institusi yang berkaitan dengan perlembagaan, seperti partai politik dan pemilu. Namun gambaran ini sangat terbatas dan tidak memberikan pandangan yang sesungguhnya tentang kajian politik. Peranan yang dimainkan oleh pemerintah, partai politik, badan-badan bukan pemerintah (NGO), pemilu, perdebatan dalam parlemen, dan persaingan dalam sebuah partai politik sememangnya merupakan unsur penting di dalam proses politik, terlebih lagi dalam proses politik modern. (Sulaiman: 2006)

Walaupun demikian, dengan hanya melihat unsur tersebut untuk mendefinisikan politik maka ibarat melihat puncak gunung es (iceberg) yang nampak ujungnya saja di permukaan lautan. Padahal, sebagian besar dari es tersebut masih lagi tersembunyi di dasar laut. Hal ini tidak bermakna, persoalan institusi politik tidak penting, tetapi pemahaman mengenai hal itu saja tidak menjelaskan pelbagai persoalan lain yang lebih mendasar dan menjadi motivasi tindakan politik seseorang. Walaupun dalam skala kecil, Leftwich coba untuk mendedahkan sesuatu yang tersembunyi di balik semua itu tetapi menjadi hakikat pelbagai dasar tindakan politik manusia.

Sebagai contoh, Leftwich (1983: 64-77) menguraikan tentang bagaimana masyarakat Maasai di Afrika yang hidup mengembala dan bersifat nomaden itu tidak terlepas dari praktik politik. Masyarakat yang hidup terasing ini bersifat berkelompok dan setiap kelompok memiliki kepala suku sebagai tempat rujukan, dan bersama binatang ternak mereka hidup berpindah-pindah. Di dalam proses berpindah kawasan tersebut, kerap kali terjadi kekhilafan melintas kawasan kelompok lain yang telah lebih dahulu menduduki kawasan tersebut. Perbuatan ini dianggap sebagai suatu trespassing. Keadaan tersebut mencetuskan konflik yang kemudian menyeret kepala suku dan pengikutnya ke dalam satu persengketaan. Dalam keadaan seperti itu, kepala suku terpaksa membuat keputusan, walaupun keputusan itu tidak dapat disamakan dengan perundang-undangan di parlemen.

Dalam konteks demikian itu, perhatian boleh juga kita tujukan kepada tulisan EvansPritchard (1969) The Nuer; Malinowski (1926) Crime and Custom in Savage Society; dan Mair (1962) Primitif Government. Masyarakat yang dikaji, walaupun hal itu dianggap masyarakat yang masih terbelakang, namun itu tidak berarti terlepas dari persoalan untuk mendapatkan "sumber" yang tidak cukup dan terpaksa membuat mekanisme pendistribusian sebagaimana layaknya masyarakat yang sudah maju. Hal itu juga melibatkan konflik antara kelompok dan peranan kepala suku, serta persaingan di antara mereka walaupun hal itu berlaku tidak dalam bentuk pemilu. Dalam proses politik mereka, pembentukan permufakatan dengan kelompok lain bisa berlaku, dan sebaliknya, konflik dan perpecahan suatu permufakatan mudah berlaku seperti juga dalam konteks politik modern. Dalam pada itu, Boissevain (1978: 232) menulis, “...everywhere people compete with each other and search for allies to help them achieve their goals. People everywhere are thus engaged in politics".

Petikan di atas menunjukkan bagaimana pentingnya proses politik, terlebih lagi jika hal itu melibatkan organisasi yang besar dan penting pula. Sebagai contoh, Bank Dunia adalah suatu organisasi yang sangat besar dan berpengaruh yang didirikan sebagai satu badan yang memberi bantuan kepada negara yang memerlukannya. Tujuan 
UNISIA, Vol. XXXI No. 70 Desember 2008

asalnya adalah untuk membantu negara yang sedang membangun, tetapi kini hubungannya tidak terbatas kepada bantuan ekonomi saja, malah ia sudah berperan dalam menentukan arah pembangunan suatu negara yang diberi bantuan tersebut. Tatkala konsep pembangunan dibincangkan dan dibuka terhadap pelbagai tafsiran, maka ia sukar dipisahkan dari urusan politik (Leftwich, 1983:88).

Sebenarnya, dasar terjadinya pelbagai konflik dalam politik adalah kepentingan yang saling bertentangan. Di dalam politik terdapat satu ungkapan Lord Palmerston yang selalu dirujuk dalam membincangkan fenomena seperti itu, yaitu "...there are no permanent friends and enemies, but permanent interests". Karena kepentingan, maka persaingan itu wujud dan muncul dalam pelbagai bentuk.

Dengan meringkaskan pelbagai rujukan yang telah dikemukakan di atas, utamanya Leftwich, kiranya hal ini dapat membawa kita kepada pemahaman yang lebih utuh tentang politik, yang dapat dirumuskan bahwa politik tidak hanya membahas hal-hal yang bersifat makro (institusi atau struktur), tetapi juga mikro (gerakan sosial, tuntutan orang ramai, dII)—sesuatu yang kerap kali luput dari perhatian para sarjana politik "konvensional".

Dengan demikian, kontestasi politik di antara para caleg di Kajang yang berujung pada konflik persaudaraan antarkeluarga, perselingkuhan politik Ammatoa, dan terjadinya dualisme kepemimpinan Ammatoa adalah juga merupakan fenomena politik. Ringkasnya, politik tidak dapat dibatasi-terlebih lagi direduksi-menjadi hanya milik suatu institusi, atau melekat pada persoalan pemerintahan saja. Politik itu ada di mana-mana, tersebar dalam hubungan-hubungan sosial.

\section{Penutup}

Hubungan sosial dan permainan politik di Kajang, pada dasarnya persis seperti penjelasan Adrian Leftwich (1983), sebagaimana saya kemukakan pada bagian sebelum penutup tulisan ini. Fenomena yang saya lihat dan alami di Kajang, sekaligus mempertegas bahwa pentingnya norma, fungsi, struktur, aturan, dan keseimbangan dalam sistem kehidupan masyarakat, ternyata tidak selalunya menjadi pedoman hidup manusia. Orang Kajang yang dikenal hidup berpandukan adat, nilai, norma, yang diatur dalam pasang, ternyata kerap juga berperilaku "menyimpang".

Intrik politik, patron-klien, tipu muslihat, dan perselingkuhan politik Ammatoa dengan Pak Dewan, seakan membenarkan sinyalemen Barrett (1996:100) bahwa kehidupan sosial memunyai banyak simpang siur dan pecahannya. Ramai orang yang melaungkan pegangan hidup yang normatif, tetapi pada kenyataannya juga melakukan pengingkaran terhadapnya. Tidak sedikit di antara mereka yang senantiasa mencari jalan pintas untuk memeroleh tujuan tanpa menurut pada adat dan norma yang berlaku.

Mengulas fenomena perselingkuhan politik Ammatoa di Kajang, saya mengutip perkataan Bailey (1970:87) yang sekiranya senafas dengan hal itu, "...kebanyakan dari kita dipengaruhi oleh kepentingan diri sendiri, acap mencoba mengingkari ikatan norma untuk mendapatkan keuntungan sebanyak mungkin." Menurut saya, keadaan inilah yang pada hakikatnya muncul di Kajang. Nilai harmoni dalam kehidupan sosial sebagaimana yang terangkum dalam pasang ri Kajang sebenarnya tidak senantiasa ada. Jika pun ada, ia hanya menjelma dalam bentuk komunitas adat yang stabil,

414 
tetapi di dalamnya penuh dengan tipu daya, muslihat, nepotisme, tikam dari belakang, jalan pintas, dan "perselingkuhan".

Tradisi dan nilai-nilai pasang ri Kajang sudah berubah. Artinya, pada batas-batas tertentu, pasang ri Kajang bukan lagi menjadi kebanggaan di dalam struktur sosial di mana mereka hidup. Ditinjau dari sistem nilai, pasang ri Kajang sudah tidak lagi menjadi aturan dalam pluralitas nilai yang berada di tengah-tengah kehidupan orang Kajang. Dalam proses selanjutnya, tokoh Ammatoa yang representatif juga tidak dijumpai lagi, sehingga komunitas Kajang sudah tidak sesolid masa lalu. Akibatnya, peran kontrol sosial Ammatoa juga menjadi melemah. Unsur-unsur dalam pasang ri Kajang telah tenggelam dalam kompleksitas modernisasi, dan politisasi elite Kajang sendiri. Dan, generasi berikutnya, lambat laun menganggap tradisi orang Kajang yang dijiwai prinsip kamase-masea tidak dapat lagi dipergunakan untuk menjawab tantangan nilai-nilai baru yang lebih relevan dan rasional. Nilai-nilai dalam pasang $r i$ Kajang telah kehilangan elan vitalnya.

Dalam konteks ini, sudah semestinya pula Ammatoa tidak tergoda untuk masuk ke kancah politik praktis, dengan mendukung salah satu caleg, tetapi tetap berkonsentrasi di bidang adat dan kemasyarakatan. Sebab, saat pemimpin adat berpolitik, maka akan muncul permasalahan, yaitu pada penggunaan otoritas dan legitimasi. Wilayah adat adalah sakral, berdimensi gerakan moral yang penuh dengan nilai-nilai keikhlasan, tanpa tendensi dan ambisi, menjadi milik semua golongan. Sedangkan dunia politik adalah profan yang meniscayakan adanya kepamrihan, penuh muatan politis, tendensius, dan akibatnya Ammatoa hanya menjadi alat politik kelompok tertentu. Jika berpolitik praktis dan menjadi juru kampanye parpol, Ammatoa sudah terjebak pada logika politik (the logic of politics) yang sering memanipulasi komunitas adat demi kepentingan politik, yang pada gilirannya menggiring ke arah logika kekuasaan (the logic of power) yang cenderung kooptatif, hegemonik, dan korup. Akibatnya, kekuatan logika (the power of logic) yang semestinya dimiliki Ammatoa, seperti logika moralitas yang mengedepankan ketulusan pengabdian terhadap masyarakat menjadi hilang, terkalahkan oleh logika kekuasaan tadi.

Akhirnya, menjelang saya tinggal di Kajang, saya menyempatkan diri ngerumpi dengan beberapa informan, membincangkan tentang pelbagai hal di Tana Toa, khususnya tentang politik. Pak Sekdes Tana Toa, Pak Desa Pattiroang, Pak Sekdes Pattiroang, Pak Kaur Pemerintahan Pattiroang, Pak Desa Sapanang, dan saya duduk di balaibalai bambu di bawah kolong rumah Pak Desa Pattiroang. Pak Sekdes Pattiroang dan Pak Kaur Pemerintahan Pattiroang mengajukan pertanyaan kepada saya. Mengapa saya mengalihkan tema penelitian dari politik identitas kepada dualisme Ammatoa. Saya hanya tersenyum, dan menjawab sekenanya. Saya bilang, apa yang saya rancang sebelum saya ke Kajang semuanya berantakan. Sebab, asumsi yang saya bangun, ternyata hanya sebagian saja benar terjadi, selebihnya tidak ada. Semua itu, hanya imajinasi saya saja sebagai peneliti. Mendengar hal itu, mereka tertawa. "Ternyata, peneliti itu, menggunakan imajinasi juga ya? Seperti mengkhayal saja," ujar Pak Kaur. Saya katakan kepada mereka, ternyata intrik politik dan dualisme Ammatoa lebih menarik bagi saya untuk dikaji. Lalu, Pak Desa Sapanang menimpali, "Orang Kajang yang dikenal orang luar sebagai orang yang sederhana dan bodohbodoh, ternyata jago main politik juga ya?" Kami semua terbahak mendengar celetukan Pak Desa Sapanang. 
UNISIA, Vol. XXXI No. 70 Desember 2008

\section{Daftar Pustaka}

Akib, Yusuf. 2003. Potret manusia Kajang. Makassar: Pustaka Refleksi

Bailey, F.G. 1970. Stratagems and spoils: A social anthropology of politics. Oxford: Basil Blackwell

Barrett, Stanley. 1996. Athropology: A student guide to theory and method. Toronto: Toronto University Press

Boissevain, J. 1978. Friends of friends: Network, manipulators, and coalitions. Oxford: Basil Blackwell

Evans-Pritchard, E.E. 1969. The Nuer. Oxford: Oxford University Press

Katu, Mas Alim. 2005. Tasawuf Kajang. Makassar: Pustaka Refleksi

Leftwich, Adrian. 1983. Redefining politics: People, resources and power. London: Metheun

Leftwich, Adrian (ed). 2004. What is politics?: The activity and its study. London: Polity
Malinowski, B. 1926. Crime and custom in savage society. London: Routledge \& Kegan Paul

Mair, L. 1962. Primitive government. Harmonsworth Middle Essex: Penguin

Salle, K. 2000. "Kebijakan lingkungan menurut pasang: Sebuah kajian hukum lingkungan adat pada masyarakat Ammatoa Kecamatan Kajang Kabupaten Daerah Tingkat II Bulukumba." Dalam Jurnal Pascasarjana Universitas Hasanuddin Vol. 1 Thn. 2000 hlm 25-30

Sanderson, Stephen K. 2000. Makro sosiologi: Sebuah pendekatan terhadap realitas sosial. Jakarta: Raja Grafindo Persada

Sulaiman, Nidzam. 2006. Pakatan dalam politik Sarawak. Bangi: UKM Press

416 